\title{
FAKTOR-FAKTOR YANG BERHUBUNGAN DENGAN KEJADIAN BENDUNGAN ASI DI KLINIK KASIH IBU DELI SERDANG TAHUN 2017
}

\section{(FACTORS CONNECTED WITH THE SUFFICIENCY OF MOTHER SUBMISSION IN DELI SERIOUS LOVE CLINIC IN 2017)}

\author{
Asrul $^{1}$, Debby Pratiwi ${ }^{2}$, \\ ${ }^{1}$ Program Studi D IV Kebidanan, Institut Kesehatan Helvetia \\ ${ }^{2}$ Program Studi D III, Akademi Kebidanan Helvetia
}

\begin{abstract}
ABSTRAK
ASI merupakan gizi sangat ideal dengan komposisi seimbang akantetapi, pemberian ASI tidak selamanya dapat berjalan normal salah satunya karena bendungan air susu yaitu pembengkakan pada payudara karena peningkatan aliran vena dan limfe menurut data WHO tahun 2013 di Amerika Serikat sebanyak 87,05\%. perempuan menyusui mengalami bendungan asi data SDKI tahun 2015 sebanyak 37,12\% ibu nifas mengalami bendungan asi. Dari data survey awal didapat, dari 10 orang ibu nifas bahwa 6 orang mengalami bendungan asi. Tujuan penelitian untuk mengetahui Faktor-Faktor Yang Berhubungan Dengan Kejadian Bendungan ASI Di Klinik Kasih Ibu Deli Serdang Tahun 2017. Jenis penelitian survei analitik dengan desain cross sectional. Lokasi penelitia Klinik Kasih Ibu Deli Serdang. Teknik pengambilan sampel adalah total population sebanyak 34 orang. Teknik pengumpulan data menggunakan kuesioner. Data dianalisis menggunakan uji Chi-Square yaitu analisis univariat dan analisis Bivariat. Hasil penelitian menunjukkan Hasil uji statistik menggunakan uji chi square, diperoleh hasil perhitungan pendidikan ( $p$ value $=0,004<\alpha$ $=0,05)$, pengetahuan $(p$ value $=0,002<\alpha=0,05)$, paritas $(p$ value $=0,003<\alpha=0,05)$, maka Ho ditolak dan Ha diterima. Kesimpulannya terdapat Pengaruh yang Berhubungan Dengan Kejadian Bendungan ASI Di Klinik Kasih Ibu Deli Serdang Tahun 2017. Disarankan tenaga kesehatan untuk memberikan penyuluhan tentang kejadian bendungan ASI melalui kerjasama lintas program dengan lembaga terkait.
\end{abstract}

\section{Kata Kunci : Pendidikan, Pengetahuan, Paritas dan Kejadian Bendungan ASI}

\section{ABSTRACT}

Breast milk is not always able to walk normally one of them because milk dams that is swelling in the breast due to increased venous flow and lymph velopes according to WHO data 2013 in the United States as much as $87.05 \%$. of breastfeeding women suffered from data damages of ICI data in 2015 as much as $37.12 \%$ of postpartum women suffered dams. From preliminary survey data obtained, from 10 postpartum mothers that 6 people suffered dam ation. The purpose of research to determine Factors Associated With Breastfeeding Incidence At Deli Serdang Ibu Bersih Clinic Year 2017. Type of research analytic survey with cross sectional design. Location researcher Klinik Kasih Ibu Deli Serdang. Sampling technique is total population of 34 people. Data collection techniques using questionnaires. Data were analyzed using Chi-Square test that is univariate analysis and Bivariat analysis. The result of the research shows that the result of statistical test using chi square test, obtained the calculation of education ( $\mathrm{p}$ value $=0,004<\alpha=0,05$ ), knowledge ( $\mathrm{p}$ value $=0,002<\alpha=0,05$ ), parity ( $\mathrm{p}$ value $=0,003<=0,05$ ), then Ho is rejected and Ha accepted. In conclusion there is Influence Associated with Breastfeeding Incidence At Deli Serdang Deli Health Clinic Year 2017. Suggested health workers to provide counseling about the incidence of milk dam through cross-program cooperation with related institutions.

\section{Keywords: Education, Knowledge, Parity and Damage Events}




\section{A. PENDAHULUAN}

Peningkatan dan perbaikan upaya kelangsungan, perkembangan dan peningkatan kualitas hidup anak merupakan upaya penting untuk masa depan Indonesia yang lebih baik. Upaya kelangsungan hidup, perkembangan dan peningkatan kualitas anak berperan penting sejak masa dini kehidupan yaitu masa dalam kandungan, bayi dan anak balita. Kelangsungan hidup anak itu sendiri dapat diartikan bahwa anak tidak meninggal pada awal-awal kehidupannya, yaitu tidak sampai mencapai usia satu tahun atau usia dibawah lima tahun

ASI merupakan sumber gizi yang sangat ideal dengan komposisi yang seimbang karena disesuaikan dengan kebutuhan bayi pada masa pertumbuhannya. ASI adalah makanan yang paling sempurna, baik kualitas maupun kuantitasnya. Jika proses menyusui dilakukan dengan teknik yang tepat dan benar, produksi ASI seorang ibu akan cukup sebagai makanan tunggal bagi bayi normal dampai dengan usia 6 bulan. ${ }^{4}$

Menurut data ASEAN pada tahun 2013 disimpulkan bahwa presentase cakupan kasus bendungan ASIpada ibu nifas tercatat 107.654 ibu nifas, pada tahun 2014 terdapat ibu nifas yang mengalami bendungan ASI sebanyak 95.698 orang, serta pada tahun 2015 ibu yang mengalami bendungan ASI sebanyak 76.543 orang dari Hal ini disebabkan karena kesadaran masyarakat dalam mendorong peningkatan pemberian ASI masih relatif rendah.

Penelitian Penti Dora Yanti pada tahun 2017, berjudul Hubungan Pengetahuan, Sikap Ibu Dengan Bendungan Asi Di Puskesmas Sidomulyo. Pekanbaru. Hasil penelitian menunjukkan p value $=0,003<\alpha$ 0,05 yang berarti ada hubungan yang bermakna antara pengetahuan tentang perawatan payudara dengan kejadian bendungan ASI dan untuk variabel sikap $\mathrm{p}$ value $=0,001<\alpha 0,05$ yang berarti ada hubungan yang bermakna antara sikap tentang perawatan payudara dengan kejadian bendungan ASI. ${ }^{5}$

Berdasarkan data yang diperoleh dari Klinik Kasih Ibu, jumlah ibu postapartum pada bulan Agustus sebanyak 34 orang. Hasil wawancara dengan 10 orang ibu nifas, didapat data bahwa 6 orang mengalami bendungan ASI. Mereka mengeluh ASI tidak keluar, payudaranya mulai keras, mulai terdapat nyeri dan disertai dengan kenaikan suhu tubuh. Sedangkan 4 orang lainnya tidak mengalami bendungan ASI. Mereka mengatakan sejak hamil sudah melakukan perawatan payudara sehingga saat menyusui tidak mengalami kendala. Berdasarkan uraian di atas maka peneliti tertarik untuk melakukan penelitian dengan judul faktor-faktor yang berhubungan dengan kejadian bendungan asi di klinik kasih ibu deli serdang tahun 2017

\section{B. METODELOGI PENELITIAN}

\section{Desain Penelitian.}

Desain yang digunakan dalam penelitian ini adalah survei analitik dengan rancangan penelitian cross sectional. Studi analitik dilakukan untuk melihat hubungan antara gejala yang satu dengan gejala yang lain, atau antara variabel satu dengan variabel lain. Penelitian cross sectional ialah penelitian untuk mempelajari dinamika korelasi dengan cara pendekatan, observasi atau pengumpulan data sekaligus pada satu waktu ${ }^{20}$

\section{Lokasi Penelitian}

Penelitian ini dilakukan di Klinik Kasih Ibu Deli Serdang .

\section{Waktu Penelitian}

Penelitian ini dilakukan pada bulan Agustus-September 2017.

\section{Populasi dan Sampel}

Populasi dalam penelitian ini adalah ibu yang melahirkan bayi berat badan lahir rendah di Rumah Sakit Umum Haji Medan Tahun 2017. Teknik pengambilan sampel pada penelitian ini menggunakan teknik Total sampling yaitu seluruh ibu yang memiliki bayi berat badan lahir rendah di Rumah Sakit Umum Haji Medan Tahun 2017 sebanyak 34 orang.

\section{Metode Pengumpulan data}

Wawancara adalah teknik pengumpulan data secara langsung oleh penelitian dengan responden atau subjek dengan cara tanya jawab sepihak secara sistematis..Pengumpulan data pada penelitian ini menggunakan kuesioner.

\section{Tujuan Penelitian}

Tujuan penelitian ini adalah untuk mengetahui adakah faktor-faktor yang berhubungan dengan kejadian bendungan asi di klinik kasih ibu deli serdang tahun 2017 


\section{Metode Analisa Data}

Metode analisa data pada penelitian ini adalah analisa univariat dan analisa bivariat. Analisa bivariat ini merupakan uji yang dilakukan dengan sifat data kuantitatif untuk mengetahui hubungan kedua variabel yang dapat dilihat pada skema dibawah ini X Variabel Independen (pengetahuan, pendidikan dan paritas) dan Y Variabel Dependent (faktor-faktor yang berhubungan dengan kejadian bendungan asi di klinik kasih ibu deli serdang tahun 2017).

\section{HASIL DAN PEMBAHASAN}

\section{Hasil Penelitian}

Tabel 1. Distribusi Frekuensi Berdasarkan Pendidikan Responden di Klinik Kasih Ibu Deli Serdang tahun 2017

\begin{tabular}{clccc}
\hline \multirow{2}{*}{ No. } & & \multirow{2}{*}{ Pendidikan } & F & Jumlah \\
\cline { 3 - 4 } & & 7 & 20,6 \\
1 & Rendah & & 19 & 55,9 \\
2 & Menengah & 8 & 23,5 \\
3 & Tinggi & Total & $\mathbf{3 4}$ & $\mathbf{1 0 0}$ \\
\hline \multicolumn{2}{r}{} \\
\hline
\end{tabular}

Berdasarkan tabel 1 diketahui responden yang memiliki pendidikan rendah yaitu sebanyak 7 orang $(20,6 \%)$, responden yang memiliki pendidikan menengah yaitu 19 orang $(55,9 \%)$, dan responden yang memiliki pendidikan tinggi yaitu sebanyak 8 orang $(23,5 \%)$.

Tabel 2. Distribusi Frekuensi Berdasarkan Paritas Responden di Klinik Kaish Ibu tahun 2017

\begin{tabular}{clcc}
\hline \multirow{2}{*}{ No. } & & \multirow{2}{*}{ Paritas } & \multicolumn{2}{c}{ Jumlah } \\
\cline { 3 - 4 } & & F & \% \\
\hline 1 & Primipara & 9 & 26,5 \\
2 & Multipara & 22 & 64,7 \\
3 & Grandemultipara & 3 & 23,5 \\
\hline \multicolumn{2}{r}{ Total } & $\mathbf{3 4}$ & $\mathbf{1 0 0}$ \\
\hline
\end{tabular}

Berdasarkan Tabel 2 diketahui responden yang kategori primipara yaitu 9 orang $(26,5 \%)$, responden dengan kategori 22 orang $(64,7 \%)$ dan responden dengan kategori Grandemultipara yaitu 3 orang $(23,5 \%)$.

Tabel 3. Distribusi Frekuensi Berdasarkan Pengetahuan Responden di Klinik Kasih Ibu tahun 2017

\begin{tabular}{|c|c|c|c|}
\hline No & Pengetahuan & $\mathbf{F}$ & Persentase (\%) \\
\hline 1 & Kurang & 8 & 23,5 \\
\hline 2 & Cukup & 20 & 58,8 \\
\hline 3 & Baik & 6 & 17,6 \\
\hline & Total & 34 & 100 \\
\hline
\end{tabular}

Berdasarkan tabel 3 dapat dilihat bahwa distribusi frekuensi pengetahuan baik yaitu sebanyak 6 orang $(17,6 \%)$, responden kategori cukup yaitu sebanyak 20 orang $(58,8 \%)$ dan kategori pengetahuan kurang yaitu 8 orang $(23,5 \%)$. 
Tabel 4. Distribusi Frekuensi Kejadian Bendungan ASI Di Klinik Kasih IbuTahun 2017

\begin{tabular}{clcc}
\hline No & Kejadian Bendungan ASI & F & Persentase (\%) \\
\hline 1 & Mengalami & 21 & 61,8 \\
2 & Tidak Mengalami & 13 & 38,2 \\
\hline & Total & $\mathbf{3 4}$ & $\mathbf{1 0 0}$ \\
\hline
\end{tabular}

Berdasarkan tabel 4 dapat dilihat bahwa distribusi frekuensi kejadian bendungan ASI mayoritas berada pada mengalami yaitu sebanyak 21 orang $(61,8 \%)$, dan minoritas berada pada kategori tidak mengalami yaitu sebanyak 13 orang $(38,2 \%)$.

\section{Analisa Bivariat}

Tabel 5. Hubungan Pendidikan Ibu Dengan Kejadian Bendungan ASI Di Klinik Kasih Ibu Deli Serdang Tahun 2017

\begin{tabular}{|c|c|c|c|c|c|c|c|}
\hline \multirow{3}{*}{ Pendidikan } & \multicolumn{4}{|c|}{ Bendungan ASI } & \multirow{2}{*}{\multicolumn{2}{|c|}{ Total }} & \multirow{3}{*}{ p.value } \\
\hline & \multicolumn{2}{|c|}{ Mengalami } & \multicolumn{2}{|c|}{ Tidak Mengalami } & & & \\
\hline & $\mathbf{f}$ & $\%$ & $\mathbf{F}$ & $\%$ & $\mathbf{F}$ & $\%$ & \\
\hline Rendah & 5 & 14,7 & 2 & 5,9 & 7 & 20,6 & \multirow{4}{*}{0,004} \\
\hline Menengah & 15 & 44,1 & 4 & 11,8 & 19 & 55,9 & \\
\hline Tinggi & 1 & 2,9 & 7 & 20,6 & 8 & 23,5 & \\
\hline Total & 21 & 61,8 & 13 & 38,2 & 34 & 100 & \\
\hline
\end{tabular}

Berdasarkan tabel 5 dapat dilihat bahwa dari 7 responden yang memiliki pendidikan rendah yang mengalami bendungan ASI sebanyak 5 orang (14,7\%). Sedangkan dari 19 responden yang memiliki pendidikan menengah yang mengalami bendungan ASI sebanyak 15 orang $(44,1 \%)$. Dan dari 8 responden yang memiliki pendidikan tinggi yang mengalami bendungan ASI sebanyak 1 orang $(2,9 \%)$. Hasil uji statistik dengan menggunakan uji chi square, diperoleh hasil perhitungan $p$ value $=0,004<\alpha=0,05$, maka Ho ditolak dan Ha diterima. Kesimpulannya terdapat Hubungan pendidikan Ibu Dengan Kejadian bendungan ASI Di Klinik Kasih Ibu Tahun 2017.

Tabel 6. Hubungan Pengetahuan Ibu Dengan Kejadian Bendungan ASI Di Klinik Kasih Ibu Deli Serdang Tahun 2017

\begin{tabular}{|c|c|c|c|c|c|c|c|}
\hline \multirow{3}{*}{ Pengetahuan } & \multicolumn{4}{|c|}{ Bendungan ASI } & \multirow{2}{*}{\multicolumn{2}{|c|}{ Total }} & \multirow{3}{*}{ p.value } \\
\hline & \multicolumn{2}{|c|}{ Mengalami } & \multicolumn{2}{|c|}{ Tidak Mengalami } & & & \\
\hline & $\mathbf{F}$ & $\%$ & $\mathbf{F}$ & $\%$ & $\mathbf{F}$ & $\%$ & \\
\hline Kurang & 6 & 17,6 & 0 & 0,0 & 6 & 17,6 & \multirow{4}{*}{0,002} \\
\hline Cukup & 14 & 41,2 & 6 & 17,6 & 20 & 58,8 & \\
\hline Baik & 1 & 2,9 & 7 & 20,6 & 8 & 23,5 & \\
\hline Total & 21 & 61,8 & 13 & 38,2 & 34 & 100 & \\
\hline
\end{tabular}

Berdasarkan tabel 6 dapat dilihat bahwa dari 6 responden yang memiliki pengetahuan kurang yang mengalami bendungan ASI sebanyak 6 orang (17,6\%). Sedangkan dari 20 responden yang memiliki pengetahuan cukup yang mengalami bendungan ASI sebanyak 14 orang $(41,2 \%)$. Dan dari 8 responden yang memiliki pengetahuan baik yang mengalami bendungan ASI sebanyak 1 orang $(2,9 \%)$. Hasil uji statistik dengan menggunakan uji chi square, diperoleh hasil perhitungan $p$ value $=0,002<\alpha=0,05$, maka Ho ditolak dan Ha diterima. Kesimpulannya terdapat Hubungan pengetahuan Ibu Dengan Pemberian ASI Eksklusif Di Wilayah Kerja Puskesmas Pabatu Tahun 2017. 
Tabel 7. Hubungan Paritas Keluarga Dengan Kejadian Bendungan ASI Di Klinik Kasih Ibu Deli Serdang Tahun 2017

\begin{tabular}{|c|c|c|c|c|c|c|c|}
\hline \multirow{3}{*}{ Paritas } & \multicolumn{4}{|c|}{ Bendungan ASI } & \multirow{2}{*}{\multicolumn{2}{|c|}{ Total }} & \multirow{3}{*}{ p.value } \\
\hline & \multicolumn{2}{|c|}{ Mengalami } & \multicolumn{2}{|c|}{ Tidak Mengalami } & & & \\
\hline & $\mathbf{F}$ & $\%$ & $\mathbf{F}$ & $\%$ & $\mathbf{F}$ & $\%$ & \\
\hline Primipara & 9 & 26,5 & 0 & 0 & 9 & 26,5 & \multirow{4}{*}{$\mathbf{0 , 0 0 3}$} \\
\hline Multipara & 9 & 26,5 & 13 & 38,2 & 22 & 64,7 & \\
\hline Grandemultipara & 3 & 8,8 & 0 & 0 & 3 & 8,8 & \\
\hline Total & 21 & 61,8 & 13 & 38,2 & 34 & 100 & \\
\hline
\end{tabular}

Berdasarkan tabel 7 dapat dilihat bahwa dari 9 responden yang memiliki paritas primipara yang mengalami bendungan ASI sebanyak 9 orang (26,5\%). Sedangkan dari 22 responden yang memiliki paritas multipara yang mengalami bendungan ASI sebanyak 9 orang (26,5\%). Dan dari 3 responden yang memiliki paritas grandemultipara yang mengalami bendungan ASI sebanyak 3 orang $(8,8 \%)$. Hasil uji statistik dengan menggunakan uji chi square, diperoleh hasil perhitungan $p$ value $=0,003<\alpha=0,05$, maka Ho ditolak dan Ha diterima. Kesimpulannya terdapat Hubungan paritas Dengan kejadian bendungan ASI Di Klinik Kasih Ibu Tahun 2017.

\section{PEMBAHASAN}

\section{Hubungan Pendidikan dengan Kejadian Bendungan ASI}

Berdasarkan data yang diperoleh dapat dilihat bahwa hasil uji statistik dengan menggunakan uji chi square, diperoleh hasil perhitungan $p$ value $=0,004<\alpha=0,05$, maka Ho ditolak dan Ha diterima. Kesimpulannya terdapat Hubungan pendidikan Ibu Dengan Pemberian ASI Eksklusif Di Wilayah Kerja Puskesmas Pabatu Tahun 2017.

Pendidikan berarti bimbingan yang diberikan seseorang terhadap perkembangan orang lain menuju kearah cita-cita tertentu yang menentukan manusia untuk berbuat dan mengisi kehidupan untuk mencapai keselamatan dan kebahagiaan. Pendidikan diperlukan untuk mendapat informasi misalnya hal-hal yang menunjang kesehatan sehingga dapat meningkatkan kualitas hidup. ${ }^{16}$

Konsep pendidikan yang merupakan suatu proses belajar yang berarti di dalam pendidikan itu terjadi proses pertumbuhan, perkembangan, atau perubahan ke arah yang lebih dewasa, lebih baik dan lebih matang pada diri individu kelompok atau masyarakat. Semakin tinggi tingkat pendidikan maka ia akan mudah menerima hal-hal baru dan mudah menyesuaikan hal-hal baru tersebut. Pendidikan orang tua atau keluarga terutama ibu bayi merupakan salah satu faktor yang penting dalam mencegah bendungan ASI. Tingkat pendidikan yang rendah akan sulit menerima arahan dalam mencegah bendungan ASI. Tingkat pendidikan yang baik akan lebih mudah dalam menyerap informasi terutama tentang pencegahan bendungan ASI. ${ }^{22}$

Hasil penelitian ini sejalan dengan penelitian Penelitian Penti Dora Yanti pada tahun 2017, berjudul Hubungan Pengetahuan, Sikap Ibu Dengan Bendungan Asi Di Puskesmas Sidomulyo Pekanbaru. Hasil penelitian menunjukkan $\mathrm{p}$ value $=0,003<\alpha 0,05$ yang berarti ada hubungan yang bermakna antara pengetahuan tentang perawatan payudara dengan kejadian bendungan ASI dan untuk variabel sikap $\mathrm{p}$ value $=0,001<\alpha 0,05$ yang berarti ada hubungan yang bermakna antara sikap tentang perawatan payudara dengan kejadian bendungan ASI. ${ }^{5}$

Hasil penelitian yang dilakukan Erna Fitrianingsih tahun 2017 yang berjudul Tingkat Pengetahuan Ibu Nifas Tentang Bendungan Asi Di BPS Al-Firdaus Kismoyoso Ngemplak Boyolali Tahun 2017. Hasil penelitian menunjukkan Tingkat pengetahuan ibu nifas tentang bendungan ASI di BPM Al-Firdaus Kismoyoso Ngemplak Boyolali diperoleh hasil pengetahuan baik sebanyak 5 responden (14\%), pengetahuan cukup sebanyak 23 responden $(66 \%)$ dan pengetahuan kurang sebanyak 7 responden $(20 \%) .{ }^{7}$

Menurut asumsi peneliti bahwa pada umumnya ibu yang mempunyai pendidikan sedang sampai tinggi dapat menerima hal-hal baru dan dapat menerima perubahan guna memelihara kesehatan khususnya tentang mencegah bendungan ASI. Mereka akan terdorong untuk ingin tahu, mencari pengalaman sehingga informasi yang didapat akan menjadi pengetahuan dan akan diterapkan pada kehidupannya. Berdasarkan penelitian yang dilakukan sebagian besar ibu mengalami bendungan ASI adalah pada tingkat pendidikan rendah dan 
menengah. Responden yang memiliki pendidikan yang lebih tinggi cenderung mudah menerima informasi baru, mereka akan aktif mencari informasi-informasi yang berguna untuk kelancaran ASI. Semakin tinggi tingkat pendidikan ibu, maka akses untuk mencari informasi akan tinggi pula.

\section{Hubungan Pengetahuan dengan Kejadian Bendungan ASI}

Hasil uji statistik dengan menggunakan uji chi square, diperoleh hasil perhitungan $p$ value $=0,002<\alpha=$ 0,05, maka Ho ditolak dan Ha diterima. Kesimpulannya terdapat Hubungan pengetahuan Ibu Dengan kejadian bendungan ASI Di Klinik Kasih Ibu Tahun 2017.

Pengetahuan adalah hasil dari "tahu", dan ini terjadi setelah seseorang melakukan penginderaan terhadap sesuatu obyek tertentu. Penginderaan terjadi melalui panca indera manusia, yakni indera penglihatan, pendengaran, penciuman, rasa dan raba. Sebagian besar pengetahuan manusia diperoleh melalui mata dan telinga. ${ }^{16}$

Faktor pengetahuan mempunyai hubungan terhadap kejadian Bendungan ASI. Artinya semakin tinggi tingkat pengetahuan seseorang tentang ASI maka akan mempengaruhi pola pikir dan sikap seseorang sehingga akan menimbulkan perilaku positif dalam mencegah bendungan ASI.

Hasil penelitian ini sejalan dengan penelitian Ika Putri Yanuarti pada tahun 2016, berjudul Faktor-Faktor Yang Mempengaruhi Pemberian Asi Eksklusif Di Puskesmas Kecamatan Grogol Petamburan, Jakarta Barat Tahun 2016. Hasil penelitian ini terdapat hubungan antara pengetahuan dengan pemberian ASI eksklusif dan terdapat hubungan dukungan keluarga dengan pemberian ASI eksklusif. Kesimpulan penelitian ini ada hubungan antara faktor pengetahuan dan dukungan keluarga dengan pemberian ASI eksklusif dan tidak ada hubungan antara faktor umur, pekerjaan, tempat persalinan dengan pemberian ASI eksklusif. ${ }^{23}$

Penelitian Meiyana Dianning Rahmawati pada tahun 2010, berjudul faktor-faktor yang mempengaruhi pemberian asi eksklusif pada ibu menyusui di kelurahan pedalangan kecamatan banyumanik kota semarang. Uji statistik menunjukkan variabel yang berpengaruh secara signifikan terhadap pemberian ASI eksklusif adalah usia ibu, status pekerjaan, urutan kelahiran bayi dan dukungan petugas kesehatan. Uji regresi logistik menunjukkan bahwa faktor paling dominan yang mempengaruhi pemberian ASI eksklusif adalah ststus pekerjaan dengan $p=0,008$ dan $\mathrm{OR}=4,137$ yang menandakan bahwa ibu yang tidak

bekerja berpeluang memberikan ASI ekskusif pada bayinya 4 kali dibanding ibu yang bekerja. Faktor-faktor yang berpengaruh terhadap pemberian ASI eksklusif pada ibu menyusui di kelurahan Pedalangan kecamatan Banyumanik kota Semarang adalah usia ibu, status pekerjaan, urutan kelahiran bayi, dukungan petugas kesehatan dan faktor yang paling dominan adalah status pekerjaan. ${ }^{24}$

Menurut asumsi peneliti, dari hasil penelitian yang dilakukan kepada 34 orang sebagian besar memiliki pengetahuan cukup dan kurangnya pengetahuan responden tentang bendungan ASI dikarenakan kurangnya keingintahuan ibu tentang bendungan ASI dan kurangnya informasi yang didapatkan dari tenaga kesehatan maupun media masa tentang perawatan payudara untuk persiapan menyusui.

Secara teoritis diketahui bahwa tingkat pengetahuan mempunyai kontribusi yang besar dalam merubah perilaku seseorang untuk berbuat sesuatu. Pengetahuan yang cukup tentang bendungan ASI akan memberikan pengaruh terhadap kejadian bendungan ASI.

\section{Hubungan Paritas dengan Kejadian Bendungan ASI}

Berdasarkan hasil uji statistik dengan menggunakan uji chi square, diperoleh hasil perhitungan $p$ value $=$ $0,003<\alpha=0,05$, maka Ho ditolak dan Ha diterima. Kesimpulannya terdapat Hubungan paritas Dengan kejadian bendungan ASI Di Klinik Kasih Ibu Tahun 2017.

Hasil penelitian Penti Dora Yanti pada tahun 2017, berjudul Hubungan Pengetahuan, Sikap Ibu Dengan Bendungan Asi Di Puskesmas Sidomulyo. Pekanbaru. Hasil penelitian menunjukkan $p$ value $=0,003<\alpha$ 0,05 yang berarti ada hubungan yang bermakna antara pengetahuan tentang perawatan payudara dengan kejadian bendungan ASI dan untuk variabel sikap $p$ value $=0,001<\alpha 0,05$ yang berarti ada hubungan yang bermakna antara sikap tentang perawatan payudara dengan kejadian bendungan ASI. ${ }^{5}$

Penelitan selanjutnya dilakukan oleh Heni Sumastri (2016) tentang lama menyusui pada post partum, diketahui bahwa dari 50 responden ibu nifas yang mengalami bendungan ASI yaitu sebanyak 16 orang (32\%). Ibu mengalami bendungan ASI adalah ibu post partum yang menyusui bayinya dengan waktu yang singkat dan tidak mengosongkan payudara secara maksimal. Dari hasil hipotesa menunjukkan adanya hubungan frekuensi dan durasi pemberian ASI dengan kejadian bendungan ASI pada Ibu nifas. ${ }^{7}$

Hasil penelitian yang dilakukan Erna Fitrianingsih tahun 2015 yang berjudul Tingkat Pengetahuan Ibu Nifas Tentang Bendungan Asi Di BPS Al-Firdaus Kismoyoso Ngemplak Boyolali Tahun 2015. Hasil penelitian 
menunjukkan Tingkat pengetahuan ibu nifas tentang bendungan ASI di BPM Al-Firdaus Kismoyoso Ngemplak Boyolali diperoleh hasil pengetahuan baik sebanyak 5 responden (14\%), pengetahuan cukup sebanyak 23 responden (66\%) dan pengetahuan kurang sebanyak 7 responden (20\%)..

Bendungan ASI terjadi karena sumbatan pada saluran ASI, tidak dikosongkan seluruhnya. Keluhan yang muncul adalah mamae bengkak ,keras, dan terasa panas sampai suhu badan meningkat. Penanganan dengan mengosongkan ASI dengan masase atau pompa, dan pengobatan simtomatis sehingga keluhan berkurang. ${ }^{14}$ Payudara hari-hari pertama sekitar 2-4 jam, payudara sering terasa penuh dan nyeri disebabkan bertambahnya aliran darah ke payudara bersamaan dengan ASI melalui di produksi dalam jumlah banyak. ${ }^{15}$ Paritas berpengaruh terhadap penerimaan seseorang terhadap pengetahuan, semakin banyak pengalaman seorang ibu maka penerimaan akan pengetahuan akan semakin mudah. Dimana sesuatu yang dialami seseorang akan menambah pengetahuan yang didapat. Pengalaman sebagai sumber pengetahuan adalah suatu cara untuk memperoleh kebenaran pengetahuan dengan cara mengulang kembali pengetahuan yang diperoleh dalam memecahkan masalah yang dihadapi dimasa lalu. ${ }^{19}$

Asumsi peneliti pengetahuan sangat berperan dalam pengeluaran ASI karena tanpa pengetahuan ,ibu akan kesulitan memberikan ASI dan tidak peduli tentang ASI dan semakin banyak paritas ibu smakin banyak pula kendala dalam pemberian ASI seperti contohnya iu merasa jenuh,bosan karena terus memberikan ASI dan mengeluh tidak sempat.

\section{KESIMPULAN DAN SARAN}

\section{Kesimpulan}

Berdasarkan hasil dan pembahasan dari penelitian hubungan anemia dan kekurangan energi kronis pada ibu hamil dengan bayi berat badan lahir rendah di rumah sakit umum haji medan dapat disimpulkan sebagai berikut : Hubungan pendidikan dengan kejadian Bendungan ASI Di Klinik Kasih Ibu Tahun 2017 didapatkan hasil uji statistik menggunakan uji chi square, diperoleh hasil perhitungan $p$ value $=0,004<\alpha=0,05$, maka Ho ditolak dan Ha diterima. Hubungan paritas dengan kejadian bendungan ASI Di Klinik Kasih Ibu Tahun 2017 didapatkan hasil uji statistik menggunakan uji chi square, diperoleh hasil perhitungan $p$ value $=0,002$ $<\alpha=0,05$, maka Ho ditolak dan Ha diterima. Hubungan paritas Dengan kejadian bendungan ASI Di Klinik Kasih Ibu Tahun 2017 didapatkan hasil uji statistik menggunakan uji chi square, diperoleh hasil perhitungan $p$ value $=0,003<\alpha=0,05$, maka Ho ditolak dan Ha diterima.

\section{Saran}

Diharapkan dapat memberikan informasi dan pelayanan yang terbaik khususnya pada ibu nifas tentang pencegahan bendungan ASI. Dan disarankan bagi tenaga kesehatan setempat untuk memberikan penyuluhan tentang kejadian bendungan ASI melalui kerjasama lintas program ataupun dengan lembaga terkait (Puskesmas pembantu dan Posyandu).

\section{DAFTAR PUSTAKA}

RI, K. K.: Profil Kesehatan Indonesia Tahun 2015. Jakarta, 2016.

Indonesia, K. K. R.: Infodatin (Situasi dan Analisis ASI Eksklusif). 2014.

Maryunani, A.: Ilmu Kesehatan Anak Dalam Kebidanan; Trans Info Media: Jakarta, 2010.

Khasanah, N.: ASI atau Susu Formula Ya; Flashbooks: Yogyakarta, 2013.

Yanti, P. D. Hubungan Pengetahuan, Sikap Ibu Dengan Bendungan Asi Di Puskesmas Sidomulyo Pekanbaru. 2017.

Antasari. Hubungan Antara Perawatan Payudara dengan Kejadian Bendungan ASI Pada Ibu Nifas di Poskesdes Sumber Baru Kecamatan Angsana Kabupaten Tanah Bumbu tahun 2016 http://idr.iainantasari.ac.id/6794/4/Bab\%201.pdf.

Quniton, U. Gambaran Perilaku Ibu Dalam Menyusui Terhadap Bendungan ASI Pada Ibu Nifas Di Polindes Barokah Kecamatan Jatirogo Kabupaten Tuban. 2012.

Ronald: Pedoman \& Perawatan Balita Agar Tumbuh Sehat dan Cerdas; Nuansa Aulia: Bandung 2011.

Widyasih, H.: Perawatan Masa Nifas; Fitramaya: Yogyakarta, 2015.

Mabud, N. H. Hubungan Pengetahuan, Pendidikan, Paritas dengan ASI Eksklusif pada Puskesmas Bahu Kecamatan Malalyang Kota Manado. 2014. 
Muhammad, I.: Panduan Penyusunan Karya Tulis Ilmiah Bidang Kesehatan Menggunakan Metode Penelitian Ilmiah; Citapustaka Media Perintis: Bandung, 2016. 